\title{
The Effectiveness City of Balikpapan-Samarinda Route Selection with User Characteristics Analysis, and Toll Tariff Analysis
}

\author{
Wendy Natalia $^{1}$, Hermanto Dwiatmoko ${ }^{2}$, Nunung Widyaningsih ${ }^{3}$ \\ ${ }^{1}$ Postgraduate Students, Department Master of Civil Engineering, Mercu Buana University, Jakarta, Indonesia \\ ${ }^{2,3}$ Postgraduate Lecturer, Department Master of Civil Engineering, Mercu Buana University, Jakarta, Indonesia
}

Corresponding Author: Wendy Natalia

\begin{abstract}
The cities of Samarinda and Balikpapan are connected by one national road with a lenght time of 3.5 hours along $\pm 125 \mathrm{~km}$. With narrow road widths, high vehicle volumes result in congestion, delays, and many accidents due to the treacherous road terrain. Then, the Balikpapan-Samarinda toll road has started operating in early 2020, with a length time of 1.5 hours along $\pm 99 \mathrm{~km}$. However, not all vehicle users choose the same route, many factors can influence the route selection decision. By distributing questionnaires and route surveys, as well as interviews. Then a statistical test is carried out through the output of the SPSS application, and using multiple regression models to predict trip generation and the factors that influence it. Analyzing toll rates using the ATP and WTP methods, as well as identifying land use along the two BalikpapanSamarinda routes. The results of the study conclude that route generation on toll roads is influenced by factors of age, income, and reasons for passing the route. Meanwhile, the arterial road is influenced by gender, income, type of vehicle, and reasons for passing the route. Analysis of the Balikpapan-Samarinda toll rate based on the Ability To Pay (ATP) approach for type 1 vehicles of Rp. 99,095 and Willingness to Pay (WTP) for type 1 vehicles of Rp 47,808, for the ideal rate for type 1 vehicles Rp 73,452<Rp 83,500 (currently applicable rates). Also, the identification of the area of land development around the two routes does not have a significant effect on the two BalikpapanSamarinda routes.
\end{abstract}

Keywords: trip generation, ATP, WTP, land use, and multiple regression.

\section{INTRODUCTION}

East Kalimantan is a province that is planned to be the location of Indonesia's a new capital city in 2024. The province of East Borneo has a relatively large area, and to hold various potentials and focuses on land development. From the abundant produce, the Provincial of East Borneo Government has declared eight special areas, that will be designated as Provincial Strategic Areas in the 2016-2036 Regional Spatial Plan Province of East Borneo.

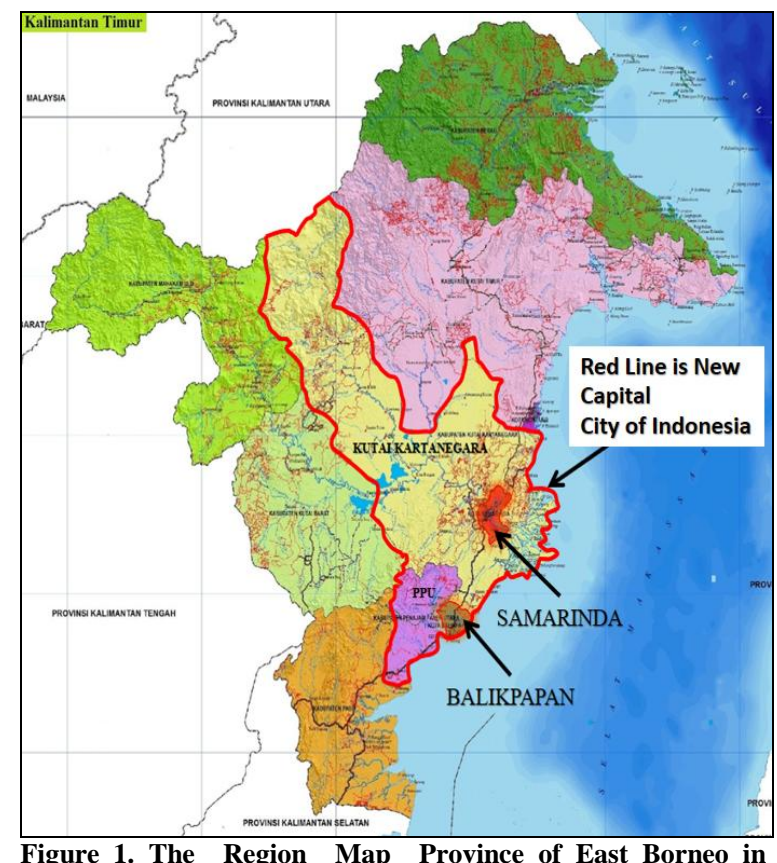

Indonesia. Source: Petatematikindo.wordpress.com, 2021. 
The special areas are the Kariangau Manufacturing Industrial Area and Buluminung located in North Penajam Paser and Balikpapan City, as well as the Industrial and Service Areas in Samarinda City. The Balikpapan-Samarinda route was previously only connected by a national road, better known as the BalikpapanSamarinda Axis Line, with a length time of 3.5 hours along $\pm 125 \mathrm{~km}$. Day by day, trip through the axis route increasing, because the width of the road is narrow, with a high volume of traffic (motorcycles, private cars, intercity buses, and heavy vehicles). This results in traffic jams, delays, and many accidents due to the terrain dangerous road. One of the solutions taken to reduce congestion, and improve safety on the road route to Samarinda City from Balikpapan City and on the contrary, as well as support the management of industrial estates. The government efforts to build road infrastructure is the construction of the Balikpapan-Samarinda Toll Road. As the implementation of the realization of an effective transportation system, for the smooth flow of distribution of commodity and passengers.

The construction of the BalikpapanSamarinda toll road began in 2016 and was completed at the end of 2019, and has been operational since early 2020, with a lenght time of 1.5 hours along $\pm 99 \mathrm{~km}$. The government hopes that this toll road, in addition to shortening time, can also be integrated with industrial and tourism areas, thus accelerating distribution access, and also the area becomes more accessible, known, and developed. The general target, government policy in road traffic and transportation is to create a transportation system in each region, so that the mobility of people and commodity can support economic growth and can meet the social and commercial needs of the community from the present to the future. With the construction of the Balikpapan-Samarinda toll road, road users who come from Samarinda to Balikpapan and on the contrary, have two alternative routes that can be passed, namely the toll road route or the national road route. With the additional traffic routes to be taken (toll road), road users who will pass the BalikpapanSamarinda road, of course can choose a trip route that can save the distance, time, and cost needed to reach a destination. However, not all road users will choose the same route, many factors can influence road users decisions in route selection.

The basis for using the method in this study was also reviewed from several previous studies, one of which was research on the Jabodetabek Commuter Railway service for the Bogor-Tanah Abang route, at Bogor Station and Manggarai Station. Where this research was also conducted a questionnaire survey, then tested for validity and reliability using SPSS software. The conclusion of the analysis using this method is: train managers need to increase the number of toilets, add first aid kits, increase the number of waiting chairs, and add stairs for platforms whose height is not the same as the train floor. In addition, it improves the performance of security officers and user awareness of priority passenger seats (Dwiatmoko, 2020). Meanwhile, in the author's research, that method used is related to the selection of two route routes from Balikpapan-Samarinda and vice versa. One of the other previous studies is the study of vehicle trip generation models and parking accumulation in three different places, namely Complex Lippo Plaza, Flobamora Mall and Hypermart Bundaran Kupang City Public Works (Frans et al., 2016). This study uses multiple regression analysis, same like this study which uses multiple regression equations to obtain a four-wheeled vehicle trip generation model on the Samarinda-Balikpapan route both on toll roads and national roads. One of the next previous studies is the determination of rates for the Ability to Pay (ATP) and Willingness to Pay (WTP) methods on the reactivation of the Bandung-Ciwidey train (Herman \& Tamara, 2020). However, in this study the ATP and WTP methods will be applied to the analysis of the Balikpapan- 
Samarinda route toll rates. Then, for the analysis of land use along the route on toll roads and national roads, it is also reviewed from several previous studies, one of which is the identification of land use changes in the Trans Sulawesi Road corridor in Amurang with a qualitative descriptive method (Josal et al., 2016).

In this study, an analysis will be carried out with several methods for the purpose, namely to:

1. Knowing the analysis of route generation on toll and national roads, and the predicted influencing factors.

2. Knowing the Balikpapan-Samarinda toll rate for facilities, based on the Ability To Pay (ATP) and Willingness To Pay (WTP) approaches.

3. Knowing the area of land use development along the toll and national roads of Samarinda and Balikpapan.



Figure 2. Balikpapan-Samarinda route: National Road and Toll Road. Source: Google Maps 2021

\section{LITERATURE REVIEW \\ Toll Road and Tariff}

According to the Government Regulation of the Republic of Indonesia Number 15 of 2005, the definition of a toll road is a public road that is part of the road network system and as a national road for which users are required to pay. Toll road transaction services, can be explained as follows (Widyaningsih, 2017):

1. Open service that is user of toll only do one transaction when entering toll gate.

2. Closed service where toll user is obliged to conduct two transactions where at the first gate entrance by taking ticket and transaction at exit toll gate in accordance with the road traversed.

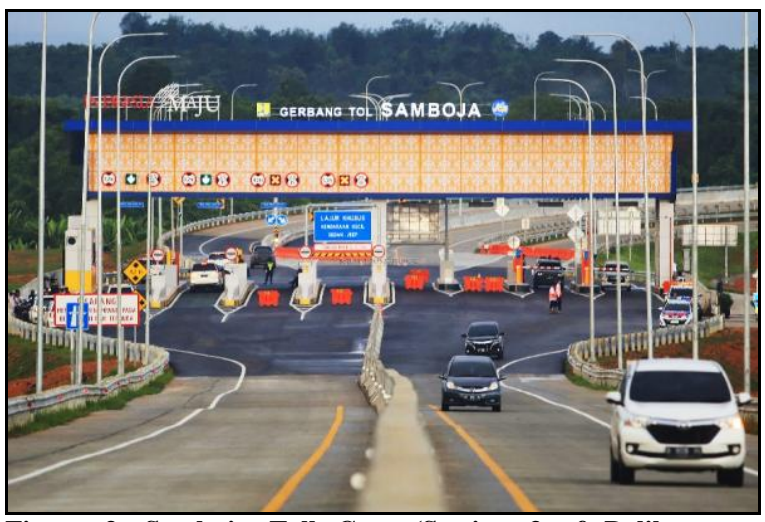

Figure 3. Samboja Toll Gate (Section 3 of BalikpapanSamarinda Toll Road).

Then, Tariff is the price of transportation services that must be paid by service users, either through the mechanism of rental agreements, bargaining, or government regulations (Warpani, 2002). According to the Law of the Republic of Indonesia Number 38 of 2004 about Roads chapter 48 , toll tariff are calculated based on the ability to pay road users, the profit from vehicle operating costs, and investment feasibility. Evaluation and adjustment of toll rates is carried out every 2 (two) years based on the effect of the inflation rate. And according to Government Regulation of the Republic of Indonesia Number 15 of 2005 about Toll Roads chapter 66, the profit on vehicle operating costs is calculated based on the difference between vehicle operating costs and the time value of the toll road and the alternative existing public roads.

\section{Land Use}

Land is the surface of the earth where various activities take place and is a limited natural resource, where its use requires planning, provision, and designation for purposes of use for the welfare of the community (Sughandy. A, 
1998). The determinants of land use are social, economic, and public interest (Jayadinata, 1999):

1. Social behavior as a determinant.

2. Determinants related to economic life.

3. Public interest as a determinant.

Chronologically, the occurrence of the need for transportation services can be illustrated in Figure 4.

\begin{tabular}{|l|}
\hline \multicolumn{1}{c|}{ VARIABLES } \\
The Land Use \\
- Activity Location Spread Pattern \\
- Density Level \\
Creating Physical Distance Between Locations \\
\hline
\end{tabular}

Calculated As Amount Of Transportation Needs

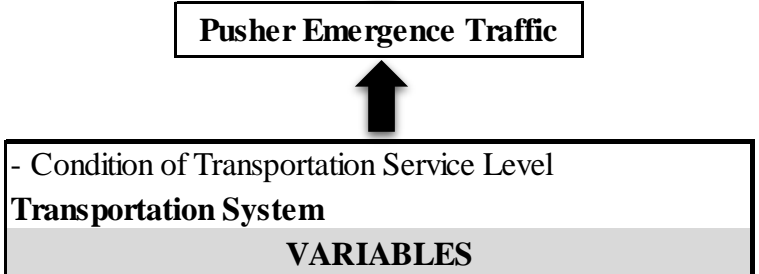

Figure 4. Chronological Flow Pusher Emergence Traffic. Source: (Miro, 2005)

The relationship between land use and transportation shows that there are many variables that affect the relationship between land use and transportation. Some of the most important variables are financial sources, industrial activity, fuel costs, supply and demand, business structure, job opportunities, and population growth (Khisty \& Lall, 2005).

\section{Transportation Concept}

\section{Definition and Functions of} Transportation

Transportation is a system consisting of infrastructure and service systems that allow movement throughout the region so that it accommodates population mobility, allows for the movement of commodity, and allows access to all areas (Tamin, 1997).

\section{City of Transportation System}

The city of transportation system can be interpreted as a unit rather than elements, as well as components that support each other and work together in the procurement of transportation that serves an area (Miro, 1997).

\section{Service Level}

The service level factors include (Morlok, 1978):

a. Traffic barriers or obstructions,

b. Freedom to maneuver,

c. Safety (accidents and other potential hazards),

d. Driving pleasure and comfort,

e. Economy (vehicle operating costs).

\section{Transport Modeling}

Transportation modeling is the planning of a transportation system in the form of physical models, such as architect models, civil engineering models, puppet shows, and others (Tamin, 1997). Transportation modeling is carried out in stages and sequentially, the stages (Miro, 2005) include: Trip Generation, Trip Distribution, Mode Choice, and Trip Assigment.

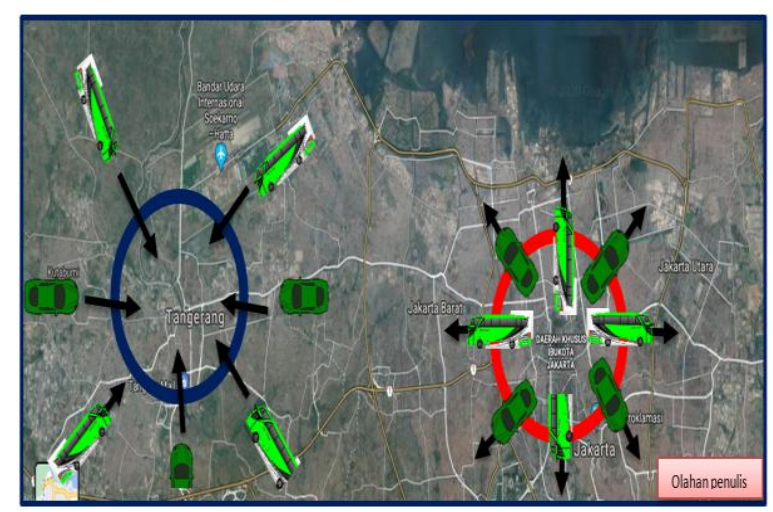

Figure 5. Example Of Trip Generation In An Area (Push And Pull). Source: by the author, 2021.

Trip generation is a modeling stage that estimates the number of movements originating from a zone or land use and the number of movements attracted to a land use or zone. The output from the calculation of traffic generation and pull is in the form of the number of vehicles, people, or commodity transport per unit time, for 
example is vehicles/hour (Tamin, 1997). The basic purpose of a movement generation is to study and predict the magnitude of the level of movement generation by studying several variations of the relationship between movement characteristics and the land use environment.

\section{Sampling Method}

The sampling method is subjective sampling, where it is not known which individual from the population will be selected as a sample, namely when the respondent who will be sampled are at the research location and want to be interviewed. The sample size is taken, referring to the Slovin formula (Umar, 2003) according to the formula:

$\mathrm{n}=\frac{N}{1+\left(N x e^{2}\right)}$

$\mathrm{n}=$ Total of Samples

$\mathrm{N}=$ Total population

$\mathrm{e}=$ Percentage of elimination for inequality, due to tolerable sampling error (can be used $1-10 \%)$.

\section{Validity}

In research states the degree of accuracy of research measuring instruments to the actual content being measured (Sugiarto \& Sitinjak, 2006). Basis of decision making for validation test (2-sided test with sig. 0.05); If the value of $r_{\text {arithmetic }}>$ $\mathrm{r}_{\text {table, }}$, then the data is declared valid. If the value of $r_{\text {arithmetic }}<r_{\text {table, }}$, then the data is declared invalid.

$$
\mathrm{r}_{\text {tabel }}=\alpha \text { and } \mathrm{df}=\mathrm{n}-2
$$

$\alpha=0.05$, with confidence is $95 \%$.

$\mathrm{n} / \mathrm{N}=$ Number of Samples.

df $=$ Degrees of Free.

\section{Reliability}

According to the researcher (Sugiyono, 2016) declare that the reliability test is so far where to which the mensuration output with use the alike object will result the alike data. The basis for making decisions in reliability testing (Sujarweni, 2014) are like follows this: When value Cronbach's Alpha (a) $>0,60$ then the questionnaire is be avowed reliable or fixed. When value Cronbach's Alpha (a) <0,60 then the questionnaire is be avowed unreliable or not fixed.

\section{Chi Square}

The chi square test is a statistical technique that is useful for testing data normality, analyzing data in the form of frequencies, and determining the size or size of the relationship, compatibility or significant difference of the analyzed variables (Susilawati et al., 2017). The basis for making decisions in the chi square test based on the table values (Santoso, 2014) are as follows:

$\alpha$ untuk $X^{2} . \alpha$ and df

$\alpha=0.05$, with confidence is $95 \%$.

$\mathrm{df}=\mathrm{df}$ value at SPSS output or;

$\mathrm{df}=$ level of freedom with formula: (b-1.k1)

$b=$ value of rows

$\mathrm{k}=$ value of columns

When the value of chi square count $>$

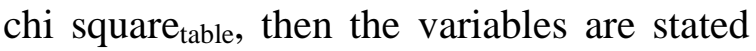
to have a relationship. If the value of chi square $_{\text {count }}<$ chi square $_{\text {table, then the }}$ variables are declared to have no relationship.

\section{Regression}

Regression analysis is an extension of the easier linear regression, which in fact shows that several independent variables simultaneously affect the dependent variable (Walpole \& Myers, 1995):

$\mathrm{Y}=\mathrm{a}+\mathrm{b}_{1} \cdot \mathrm{x}_{1}+\mathrm{b}_{2} \cdot \mathrm{x}_{2}+\ldots+\mathrm{b}_{\mathrm{z} \cdot \mathrm{x}_{\mathrm{z}}}$

$\mathrm{Y}=$ dependent variable

$\mathrm{A}=$ regression constant

$\mathrm{x}_{1} \ldots \mathrm{x}_{\mathrm{z}}=$ independent variable

$b_{1} \ldots b_{z}=$ regression coefficient 


\section{Ability To Pay And Willingness To Pay}

Ability to pay (ATP) is the amount of people's ability to pay for the services they use. The factors that affect ATP consist of the amount of income, transportation needs, intensity or frequency of travel, transportation costs, and the percentage of income used for transportation costs. Meanwhile, Willingness to pay (WTP) is the willingness of service users to pay for services obtained. The factors that influence the amount of WTP are the products offered by service providers, the quantity and quality of the products provided, the user's utility for these transportation services, and the behavior or characteristics of users (Winaya \& Caroline, 2019) Determination of ATP Value can be determined by the following equation (Rumtily \& Setiawan, 2019) :

$$
\mathrm{ATP}=\frac{L x \cdot P p \cdot P t}{T r}
$$

$\mathrm{ATP}=$ respondent's ability to pay $(\mathrm{Rp})$

$\mathrm{Lx}=$ income level of respondents per month (Rp)

$\mathrm{Pp}=$ percentage of income for transportation per month

$\mathrm{Pt}=$ percentage of transportation costs used for transportation services

$\operatorname{Tr}=$ frequency of respondent's trips per month

Determination of the WTP value can be determined by the following equation (Raffel et al., 2015) namely:

$$
\mathrm{WTP}=\mathrm{T}+\mathrm{B}
$$

$\mathrm{T}=$ current feasible transport fare according to passenger

$\mathrm{B}=$ costs that need to be added for service improvement

In principle, in determining fares, it can be viewed from several main aspects that exist in the public transportation system, including:

1. User

2. Operators

3. Regulatory government

\section{Relationship ATP and WTP}

Tariff determination that often occurs is a clash between Willingness to Pay and Ability to Pay (Tamin et al., 1999), this condition can be seen in the illustration in Figure 6. The relationship between ATP and WTP occurs as follows:

\section{WTP $<$ ATP,}

This means that the ability to pay is greater than the desire to pay for the services that have been used. This could happen when the user gets big income. However, satisfaction with the services obtained is lower, this is usually referred to as Choice Riders.

\section{ATP $<$ WTP}

In this condition it is inversely proportional to the condition of WTP < ATP, where in this condition the user have a wish to pay for the service superior to the ability to pay for it. Things like this could happen to users who have fewer incomes, however the satisfaction level of services is very high. So, the wish to pay for public service facilities is more likely to be affected because of the facilities received by the user, this condition is called Captive Riders.

\section{3. $\mathbf{W T P}=\mathbf{A T P}$}

The willingness and ability to pay for services that have been used have the same level. This situation declares that satisfaction with the use of services that have been received is Balanced with the tariffs issued.

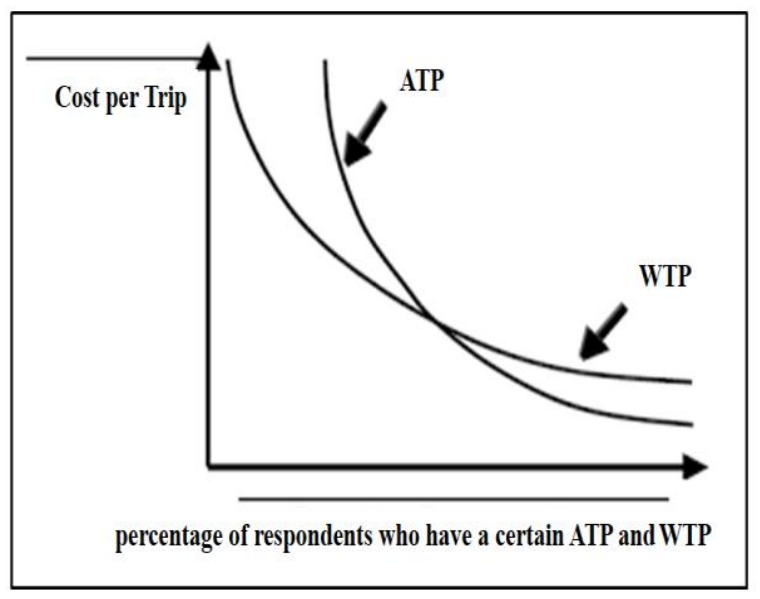

Figure 6. Relationship between ATP and WTP. Source: (Tamin et al., 1999). 


\section{MATERIALS \& METHODS}

This type of research design is descriptive quantitative. Sources of data use, namely primary data by direct observation of the field, distributing questionnaires and interviewing respondents for the required data. The survey of vehicle volume data was conducted in the 4th week of October 2020. The types of vehicles surveyed are the type I until type $\mathrm{V}$ (in toll roads-including national roads). Observation to road routes does at same with a vehicle volume surveys. It is done for a week, from Monday to Sunday, the largest volume of vehicles will is taken and does at 06.00 - 21.00. Distribution of questionnaires (revealed preference) was distributed to users who had jobs that had crossed toll roads and national roads. Users are people who have trip activities from Samarinda to Balikpapan and from Balikpapan back to Samarinda.

There are some variables had included in the questionnaire that was used in this study. For the questionnaire type I, about user characteristics, including: The Gender (X1), The Age (X2), Education (X3), A Job (X4), An Income (X5), Total Ownership of Four-Wheel Vehicles (X6), Type of Vehicle Class ( X7), Type of Trip Activities (X8), Selected Road Route (X9), Reason For Passing Route (X10), and The Trip Frequency (Y).

For the type II questionnaire, about the description of ATP and WTP questions, including:

1. Average income allocation of respondents for transportation costs each month (\%) ?

2. The Average monthly transportation a cost allocation for the toll route usage (\%) ?

3. According to the respondent's opinion, the appropriate toll tariff? (the assessment must be based on the quality of toll services)

4. If there is an increase in the quality of toll services, is respondents willing to pay more for the service (Yes/No)?
5. How much rupiah will the respondent add to improve the quality of the service?

6. How many trips does the respondent take in a month (SamarindaBalikpapan)?

The data analysis method in this study includes three targets that have their own data input and data analysis techniques. The first is statistical analysis by multiple linear regression with application International Business Machines Statistical Package for the Social Sciences (IBM SPSS) Version 22. To identify and perform instrument testing on the characteristics of users of four-wheeled vehicles that pass through toll road routes and national roads. So that to get the value of the generation model that passes through the SamarindaBalikpapan route, and the factors that influence it. Second, the analysis uses the ATP and WTP methods, to find out the amount of tariffs for toll road routes, based on route user respondents. And third, is the use of multiple regression analysis to analyze the land use area of the SamarindaBalikpapan route, along toll roads and national roads, whether there is a significant effect or not.

\section{RESULT AND DISCUSSION Vehicle Traffic Volume}

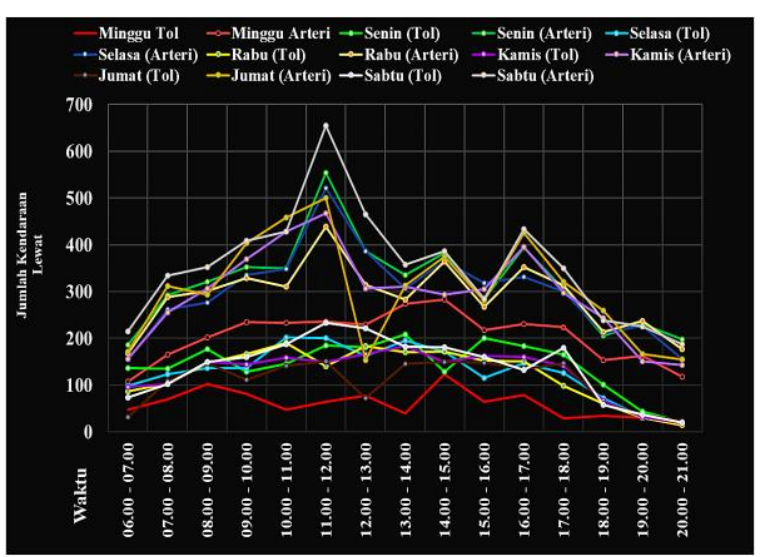

Figure 7. Graph of Daily Vehicle Traffic Volume From Sunday-Saturday. Source: Analysis Results, 2021.

From the graph in the figure 7 , for the Balikpapan-Samarinda route. The highest traffic is at 11.00-12.00 on Saturday, 
as many as 655 vehicles/hour on the national route, and 233 vehicles/hour on toll roads which are dominated by the class I vehicles.

\section{Identification}

By using equation (1) with a population of 886806 people in Samarinda City with an error value of $6 \%$, get the total of questionnaire samples distributed is 300 respondents. And the characteristics, the outcome of the identification from respondents answers as a whole that passed through the Samarinda-Balikpapan route is; Male sex $62 \%$ (X1), aged 20-40 years $57.33 \%$ (X2), graduate education is high school $42.33 \%$ (X3), have a job is enterpriser /entrepreneur $51.67 \%$ (X4), have income $<\mathrm{Rp} 5,000,000 \quad 43.67 \%$ (X5), owning a four-wheeled vehicle $<3$ units $78.67 \%$ (X6), The type of vehicle class owned is type I $74.33 \%$ (X7), the type of trip activity is work $87.00 \%$ (X8), the majority of the selected road routes are national roads $70.00 \%$ (X9), the reason for going through the majority route (national road), is because the cost is cheaper $53.67 \%$ (X10), and the total of trips is 10-20 times a month $47.33 \%$ (Y). Identification of specific characteristics, both through toll roads and nationally, can be seen in the following table:

\begin{tabular}{|c|c|c|}
\hline $\begin{array}{c}300 \\
\text { Respondents } \\
\text { Variabels }\end{array}$ & $\begin{array}{c}90 \text { Respondents Chose } \\
\text { Toll Roads }\end{array}$ & $\begin{array}{l}210 \text { Respondents Chose } \\
\text { National roads }\end{array}$ \\
\hline $\mathbf{X 1}$ & $54,44(\%)$ Female & $69,05(\%)$ Male \\
\hline $\mathbf{X} 2$ & $63,33(\%) \quad 20-40$ years old & $54,76(\%) 20-40$ years old \\
\hline $\mathbf{X 3}$ & 45,56 (\%) Bachelor & 52,38 (\%) High School \\
\hline X4 & $52,22(\%) \begin{array}{l}\text { Government } \\
\text { Employees }\end{array}$ & $59,52(\%)$ Enterpriser \\
\hline X5 & $40,00(\%)<\operatorname{Rp} 5.000 .000$ & $45,24(\%)<\operatorname{Rp} 5.000 .000$ \\
\hline X6 & $86,67(\%)<3$ units & $75,24(\%)<3$ units \\
\hline $\mathbf{X} 7$ & $81,11(\%)$ Type I & 71,43 (\%) Type I \\
\hline X8 & $85,56(\%)$ Work & $87,62(\%)$ Work \\
\hline X9 & - & - \\
\hline $\mathbf{X 1 0}$ & 46,67 (\%) Short Trip Time & $70,48(\%)$ Low Cost \\
\hline $\mathbf{Y}$ & $48,89(\%)<10$ times & $53,81(\%) \quad 10-20$ times \\
\hline
\end{tabular}

\section{Instrument Test}

In this study, a questionnaire was made with 11 variables (all variables $X$ and $Y)$ with a significance of $5 \%$ by IBM SPSS V.22. The testing phase of the 300 questionnaire results will be divided into 2, namely the results of the toll route selection questionnaire of 90 respondents, and the national route of 210 respondents, because of that, the X9 variable (Selected Travel Route) is not used.

\section{Validity}

In this test, the value of the validity of the variables $\mathrm{X} 1, \mathrm{X} 2, \mathrm{X} 3, \mathrm{X} 4, \mathrm{X} 5, \mathrm{X} 6$, $X 7, X 8$, and $X 10$, to the $Y$ variable will be tested. For validity testing using equation (2) with a significance value of $5 \%$. For the toll route selector, the value of $\mathrm{df}=90-2=$ 88 , with $\mathrm{r}_{\text {table }}=0.207$. Then, the national route selector, the value of $\mathrm{df}=210-2=$ 208 , with $r_{\text {table }}=0.135$. The value of $r_{\text {count }}$ and test results can be seen in table 2 and table 3.

Table 2. Validity Test Result (Toll Routes)

\begin{tabular}{cccc}
\hline Var. & $\mathbf{R}_{\text {count }}$ & $\mathbf{R}_{\text {table }}$ & Test Outcome \\
\hline X1 & 0,206 & $<0,207$ & Invalid \\
\hline X2 & 0,564 & $>0,207$ & Valid \\
\hline X3 & 0,257 & $>0,207$ & Valid \\
\hline X4 & 0,442 & $>0,207$ & Valid \\
X5 & 0,772 & $>0,207$ & Valid \\
X6 & 0,444 & $>0,207$ & Valid \\
X7 & 0,234 & $>0,207$ & Valid \\
\hline X8 & 0,087 & $<0,207$ & Invalid \\
\hline X10 & 0,336 & $>0,207$ & Valid \\
\hline \multicolumn{5}{c}{ Source: Analysis Results, 2021}
\end{tabular}

Table 3. Validity Test Result (National Routes)

\begin{tabular}{cccc}
\hline Var. & $\mathbf{R}_{\text {count }}$ & $\mathbf{R}_{\text {table }}$ & Test Outcome \\
\hline X1 & 0,367 & $>0,135$ & Valid \\
X2 & 0,310 & $>0,135$ & Valid \\
\hline X3 & 0,016 & $<0,135$ & Invalid \\
\hline X4 & 0,536 & $>0,135$ & Valid \\
\hline X5 & 0,500 & $>0,135$ & Valid \\
X6 & 0,142 & $>0,135$ & Valid \\
X7 & 0,356 & $>0,135$ & Valid \\
\hline X8 & 0,484 & $>0,135$ & Valid \\
X10 & 0,456 & $>0,135$ & Valid \\
\hline \multicolumn{5}{c}{ Source: Analysis Results, 2021} \\
\end{tabular}

Because the value of $r_{\text {count }}<r_{\text {table, }}$, so the variable is invalid. This means that the questions of $\mathrm{X}$ variable cannot be used to measure questions to the $\mathrm{Y}$ variable.

\section{Reliability}

For the reliability testing, all variables $(\mathrm{X}$ and $\mathrm{Y})$ in the questionnaire as a 
whole are avowed consistent or reliables. For toll routes, the value of Cronbach's alpha (a) is $0.748>0.60$. For national routes, the value of Cronbach's alpha (a) is $0.702>0.60$. Because the alpha value is greater than the conditional value is 0.60 , so the variables are reliable. This means, that if all the questions in the questionnaire are obtained in accordance with reality, no matter how many times the data is collected, the results will remain the same or consistent.

\section{Chi Square}

In this test, variables use is $\mathrm{X} 1, \mathrm{X} 2$, $\mathrm{X} 3, \mathrm{X} 4, \mathrm{X} 5, \mathrm{X} 6, \mathrm{X} 7, \mathrm{X} 8$, and X10. For the chi square test using equation (3) with $X^{2} \alpha$ $=X^{2} .0 .05$ and $\mathrm{df}=2$ dan 4 (from SPSS app.) dengan chi square table $=5,991$ and 9,488 . The value of chi square count and test outcome can be seen in table 4 and table 5 .

Table 4. Chi Square Test Result (Toll Routes)

\begin{tabular}{|c|c|c|c|}
\hline Var. & $\begin{array}{c}\text { Chi } \\
\text { Square }_{\text {count }}\end{array}$ & $\begin{array}{c}\text { Chi } \\
\text { Square }_{\text {table }}\end{array}$ & Test Outcome \\
\hline X1 & 9,116 & $>5,991$ & has a relationship \\
\hline $\mathbf{X} 2$ & 31,105 & $>9,488$ & has a relationship \\
\hline $\mathbf{X 3}$ & 3,908 & $<9,488$ & has no relationship \\
\hline $\mathbf{X} 4$ & 16,307 & $>9,488$ & has a relationship \\
\hline X5 & 58,375 & $>9,488$ & has a relationship \\
\hline X6 & 21,810 & $>9,488$ & has a relationship \\
\hline $\mathbf{X 7}$ & 10,170 & $>9,488$ & has a relationship \\
\hline X8 & 15,885 & $>9,488$ & has a relationship \\
\hline $\mathbf{X 1 0}$ & 44,418 & $>9,488$ & has a relationship \\
\hline
\end{tabular}

Table 5. Chi Square Test Result (National Routes)

\begin{tabular}{|c|c|c|c|}
\hline Var. & $\begin{array}{c}\text { Chi } \\
\text { Square }_{\text {count }}\end{array}$ & $\begin{array}{c}\text { Chi } \\
\text { Square }_{\text {table }}\end{array}$ & Test Outcome \\
\hline X1 & 35,170 & $>5,991$ & has a relationship \\
\hline $\mathbf{X} 2$ & 3,071 & $<9,488$ & has no relationship \\
\hline $\mathbf{X} 3$ & 25,882 & $>9,488$ & has a relationship \\
\hline $\mathbf{X 4}$ & 112,391 & $>9,488$ & has a relationship \\
\hline X5 & 84,270 & $>9,488$ & has a relationship \\
\hline X6 & 6,964 & $<9,488$ & has no relationship \\
\hline $\mathbf{X 7}$ & 66,613 & $>9,488$ & has a relationship \\
\hline X8 & 85,725 & $>9,488$ & has a relationship \\
\hline X10 & 108,287 & $>9,488$ & has a relationship \\
\hline
\end{tabular}

\section{Trip Generation}

Using equation (4), the regression value for the trip generation model for the Samarinda-Balikpapan route via the toll road, based on the respondent's perception is $\mathrm{Y}=-0.522+0.209 . \mathrm{X} 1+0.300 . \mathrm{X} 2-$ 0.197.X3 - 0.025.X4 + 0.419.X5 + 0.050.X6
$+0.128 . \mathrm{X} 7+0.108 . \mathrm{X} 8+0.300 . \mathrm{X} 10$, and tested again for a positive value and get the new model value is $\mathrm{Y}=0.009+0.193 . \mathrm{X} 2+$ 0.436.X $5+0.259$.X10. From this model, the factors that most influence respondents' decisions on the frequency of trips via toll roads is The Age, Income and Reasons for Passing the Route.

Then, the regression value for the trip generation model for the SamarindaBalikpapan route via the national road, based on the respondent's perception is $\mathrm{Y}=$ $0.117+0.202 . \mathrm{X} 1-0.131 . \mathrm{X} 2+0.101 . \mathrm{X} 3+$ $0.126 . \mathrm{X} 4+0.306 . \mathrm{X} 5-0.041 . \mathrm{X} 6+0.171$. $\mathrm{X} 7$ - 0.109.X8 + 0.308.X10, and tested again for a positive value and get the new model value obtained is $\mathrm{Y}=0.094+$ 0.164.X1 + 0.285.X5 + 0.204.X7 + 0.314 .X10. From this model, the factors that most influence the respondent's decision on the frequency of trips via national roads is Gender, Income, Type of Vehicle Class, and Reasons for Passing the Route.

\section{ATP and WTP Method}

In Figure 7, it can be seen that if the type of vehicle class is dominated by the type of class I vehicle. Then the calculation of the ATP and WTP methods will be carried out on the type of vehicle class I on toll routes only. There are several factors that affect ATP, namely monthly income, percentage of transportation costs and frequency of trips. The calculation of the ATP method using equation (5) is shown in the complete research paper. The result is that out of 90 respondents using toll roads, there are 73 respondents using class I vehicles. Of these 73 respondents, there are 40 respondents who are able to pay the

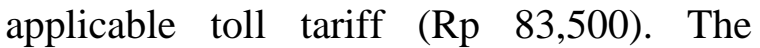
amount of tariffs that can be paid by the ability of users of the SamarindaBalikpapan Toll Road ranges from Rp. 11.081 until Rp. 625.000.

There are several factors that affect WTP, namely the rate according to the respondent, and the willingness to pay for facility repairs. The calculation of the WTP method using equation (6) is presented in 
the complete research paper. As a result, of the 90 respondents who use toll roads, there are 73 respondents who use class I vehicles. Of the 73 respondents, there are 26 respondents who are willing to pay for services to improve toll facilities. The amount of tariffs that can be paid by users of the Samarinda-Balikpapan Toll Road ranges from Rp. 25.000 up to $\mathrm{Rp}$. 95.000 .

From the calculation of ATP and WTP, the average value is the ATP value > WTP value. This shows that the respondent's ability is greater than the willigness. This can happen, because users have relatively high incomes, but the willingness to pay for toll facilities is relatively low, it can be concluded that travelers from Samarinda-Balikpapan in this condition are called Choiced Riders.

The ideal tariff based on ATP and WTP analysis is the quotient of the average ATP and WTP analysis, which is Rp73.452 $<$ Rp83.500 (currently applicable rates). The calculation can be seen below:

Average ATP rate $=\mathrm{Rp} 99.095$

Average WTP rate $=\mathrm{Rp} 47.808$

Analysis of the ideal tariff $=$ Rp. $99.095+$ Rp. 47.808) / $2=$ Rp. 73.452 .

\section{Identification of Land Use Area}

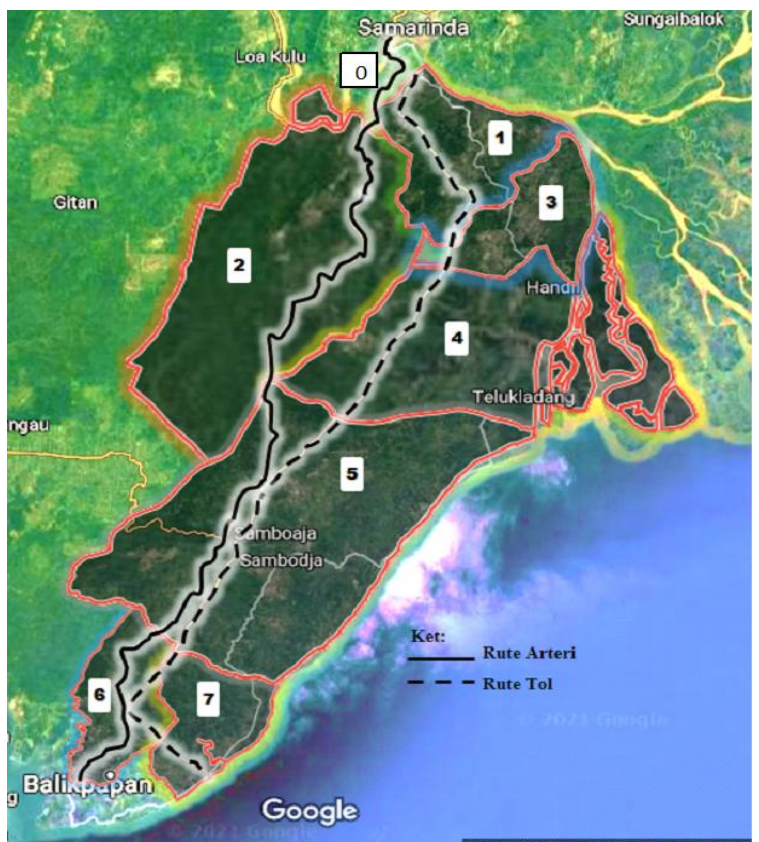

Figure 8. Map of Sub-Districts Along the SamarindaBalikpapan Route, on National and Toll Road. Source: Google Maps, 2021
For the identification of conditions and development of land use along toll roads and national roads, there are no significant changes, because along the land area the road is a green open space and forest protected by the government. The position of the sub-district area can be seen from the number shown in Figure 8, there are eight sub-districts that are part of three districts, namely Samarinda City District, Kutai Kartanegara District, and Balikpapan City District.

There is also a development of land use area in Samarinda City and Balikpapan City obtained from secondary data, there are several names of areas crossed by the Samarinda-Balikpapan route, both national and toll roads, can be seen in table 6 .

\begin{tabular}{|c|c|c|c|c|c|c|}
\hline \multirow{2}{*}{ نั } & \multirow{2}{*}{ Sub-District } & \multirow{2}{*}{$\begin{array}{c}\text { An Area } \\
\left(\mathbf{k m}^{2}\right)\end{array}$} & \multirow{2}{*}{$\begin{array}{c}\text { Total of } \\
\text { Population } \\
\text { (people) }\end{array}$} & \multirow{2}{*}{$\begin{array}{c}\text { Agricultural/ } \\
\text { Plantation } \\
\text { Land Use } \\
\left(\mathbf{k m}^{2}\right) \\
\end{array}$} & \multicolumn{2}{|c|}{ Route Length (km) } \\
\hline & & & & & Toll & National \\
\hline $\mathbf{0}$ & $\begin{array}{l}\text { Samarinda } \\
\text { Seberang Kab. } \\
\text { Kota Samarinda }\end{array}$ & 9,82 & 64262 & 0,00 & & 2,03 \\
\hline 1 & $\begin{array}{l}\text { Palaran Kab. } \\
\text { Kota Samarinda }\end{array}$ & 221,29 & 63872 & 16,17 & & \\
\hline 2 & $\begin{array}{l}\text { Palaran Kab. } \\
\text { Kota Samarinda }\end{array}$ & 221,29 & 63872 & 16,17 & 22,74 & \\
\hline 3 & $\begin{array}{l}\text { Loa Janan Kab. } \\
\text { Kutai } \\
\text { Kartanegara }\end{array}$ & 644,20 & 61974 & 78,61 & & 64,97 \\
\hline 4 & $\begin{array}{l}\text { Sanga-sanga } \\
\text { Kab. Kutai } \\
\text { Kartanegara }\end{array}$ & 233,40 & 18812 & 5,62 & 2,43 & \\
\hline 5 & $\begin{array}{l}\text { Muara Jawa } \\
\text { Kab. Kutai } \\
\text { Kartanegara }\end{array}$ & 619,16 & 37974 & 19,28 & 20,24 & \\
\hline 6 & $\begin{array}{l}\text { Samboja Kab. } \\
\text { Kutai } \\
\text { Kartanegara }\end{array}$ & 700,83 & 65678 & 121,28 & 31,03 & 31,81 \\
\hline 7 & $\begin{array}{l}\text { Balikpapan Utara } \\
\text { Kab.Kota } \\
\text { Balikpapan }\end{array}$ & 132,16 & 160900 & 18,07 & 13,80 & 25,79 \\
\hline 8 & $\begin{array}{l}\text { Balikpapan Timur } \\
\text { Kab.Kota } \\
\text { Balikpapan }\end{array}$ & 137,16 & 71067 & 0,00 & 8,13 & \\
\hline \multicolumn{5}{|c|}{ Jumlah } & $\mathbf{9 8 , 3 7}$ & 124,60 \\
\hline
\end{tabular}

To model whether or not the value of land use influence on the SamarindaBalikpapan route, the value of the variable is determined based on the description of the statistical data in table 6 . The values are set:

$\mathrm{X} 1=\mathrm{An}$ area, 
$\mathrm{X} 2=$ Total of Population,

$\mathrm{X} 3$ = Land use,

$\mathrm{Y} 1=$ Length of toll route that passes through a certain sub-district, and

Y2 = Length of the national route that passes through a certain sub-district.

Then, an analysis with using the SPSS Ver.22 application, and the results of the SPSS output that were seen, the regression model was obtained:

$\mathrm{Y} 1=1.4898+0.0234 . \mathrm{X} 1+0.00 . \mathrm{X} 2+$ 0.0792.X3 for toll routes.

$\mathrm{Y} 2=-10.1834+0.2393 . \mathrm{X} 1+0.00015 . \mathrm{X} 2-$ 1.1264.X3 for national routes.

From the regression results, all $\mathrm{X}$ variables values are below the value of 0.3 , some even have a minus value. So the conclusion obtained is that there is not much connection or influence between the length of toll and national routes to the area, population, and land use.

\section{CONCLUSION}

Based on all the brief analysis above. So, the conclusions in this study include the following:

1. Trip generation on toll roads is influenced by some factors, like age, income and reasons for passing the route. Meanwhile, the route on the national road is influenced by some factors, like gender, income, type of vehicle class, and reasons for passing the route.

2. The Samarinda-Balikpapan toll tariff, for class I vehicles, is based on the Ability To Pay (ATP) approach is Rp. 99.095 and Willingness To Pay (WTP) approach is Rp. 47.808, and for the ideal tariff is Rp. $73.452<\mathrm{Rp} 83.500$ (currently applicable tariff) .

3. The area of land use development for plantations/agriculture along the Samarinda-Balikpapan toll road route is $16.17 \mathrm{~km}^{2}$ in the Palaran area, $5.62 \mathrm{~km}^{2}$ in the Sanga-sanga area, $19.28 \mathrm{~km}^{2}$ in the Java Muara area, and $0 \mathrm{~km}^{2}$ in the East Balikpapan area. Meanwhile, the area of land use development for plantations/agriculture along the national road of the Kota SamarindaBalikpapan route is $78.61 \mathrm{~km}^{2}$ in the Loa Janan area, $121.28 \mathrm{~km}^{2}$ in the Samboja area, and $18.07 \mathrm{~km}^{2}$ in the North Balikpapan area and $0 \mathrm{~km}^{2}$ in the Across of Samarinda area. And the length of the Samarinda-Balikpapan route that passes through several subdistricts not have much relationship or influence to land use statistical data.

\section{SUGGESTIONS}

Suggestions that can be given to complete and support this research are:

1. There needs to be a re-arrangement for toll rates, so that travellers from Samarinda-Balikpapan want to partially switch or are interested in toll routes from national roads.

2. There needs to be an appeal to the public from Jasa Marga, to use the toll route, so that the old route (national) does not have too many tripper, so it does not cause long traffic jams, and prevents frequent accidents, as well as delays in logistics distribution.

3. There is a need for arrangements for better views of toll and national routes, related to the utilization of plantation, agricultural space, and increasing road users to be more comfortable passing these routes, considering the current condition has been neglected.

One example: such as on toll routes, a place for resting for toll visitors is a rest area. Rest area visitors can relax more freely, choose a place to rest or eat, while enjoying a beautiful view of the plantation/agriculture/protected forest area around the toll road, so that it can be an attraction for travellers to switch to using the toll route for some time when travelling from SamarindaBalikpapan or vice versa. So that it can balance the flow of vehicle volume in both lanes.

4. It is necessary to re-plan the tariff setting system, during the covid 
pandemic and after the Covid pandemic there is no longer any. So there is a comparison between having covid and after covid. Because there be differences in characteristics by users, so that rates can match people's abilities and willingness.

\section{Acknowledgement: None}

\section{Conflict of Interest: None}

\section{Source of Funding: None}

\section{REFERENCES}

1. Dwiatmoko, H. (2020). Applying Important Performance Analysis for Jabodetabek Commuter Train Services. International Journal Of Supply Chain Management, 9(2).

2. Frans, J. H., Utomo, S., \& Normandiri, A. E. (2016). Model Tarikan Pergerakan Transportasi Pada Kompleks Lippo Plaza, Flobamora Mall Dan Hypermart Bundaran Pu Kota Kupang. Jurnal Teknik Sipil, 5(2), 149-162.

https://garuda.ristekbrin.go.id/documents/de tail/960210

3. Herman, \& Tamara, R. (2020). Penetapan Tarif pada Reaktivasi Kereta Api BandungCiwidey dengan Metode Ability to Pay (ATP) dan Willingness to Pay (WTP). Jurnal Online Institut Teknologi Nasional, 6(1).

4. Jayadinata, J. T. (1999). Tata Guna Tanah dalam Perencanaan Pedesaan Perkotaan dan Wilayah. ITB.

5. Josal, T., Windy, M., \& Lahamendu, V. (2016). Identifikasi Perubahan Penggunaan Lahan Koridor Jalan Trans Sulawesi Di Amurang. Jurnal Teknik Sipil, 5(2), 9-19.

6. Khisty, C. J., \& Lall, B. K. (2005). Dasardasar Rekayasa Transportasi (Penerjemah: Fidel Niro). Erlangga.

7. Miro, F. (1997). Sistem Transportasi Kota. Tarsito Bandung.

8. Miro, F. (2005). Perencanaan Transportasi untuk Mahasiswa, Perencana, Dan Praktisi. Erlangga.

9. Morlok, E. K. (1978). Introduction to Transportation Engineering and Planning. Mc Graw Hill Kogakusha Ltd. https://elibrary.dephub.go.id/opac/pencarian
sederhana?action=pencarianSederhana\&rua $\mathrm{s}=$ Pengarang\&bahan=Semua Jenis

Bahan\&katakunci=Edward K Morlok

10. Raffel, A. F., Rachmansyah, A., Soemarno, \& Kumurur, V. A. (2015). Analysis of Willingness and Ability to Pay (WTP and ATP) On Waste Management in the City Ternate. IOSR Journal of Environmental Science, Toxicology and Food Technology, 9(5), 39-48. https://doi.org/10.9790/240209523948

11. Rumtily, A. D. I., \& Setiawan, R. (2019). Kemampuan Dan Kesediaan Membayar Pengguna Bus Trans Sidoarjo. Jurnal Transportasi, Volume 19(1 April 2019), 3138.

12. Santoso, S. (2014). Statistik Parametrik Edisi Revisi. Jakarta: Elex Media Komputindo.

13. Sughandy. A. (1998). Penataan Ruang Dalam Pengelolaan Lingkungan. Grasindo.

14. Sugiarto \& Sitinjak, T. (2006). Strategi Menaklukkan Pasar Melalui Riset Ekuitas dan Perilaku Merek. Jakarta: Gramedia Pustaka Utama.

15. Sugiyono. (2016). Metode Penelitian Kuantitatif, Kualitatif, dan R\&D (XXIII). Bandung: Alfabeta, CV.

16. Sujarweni, V. W. (2014). Metodologi Penelitian Lengkap, Praktis, dan Mudah Dipahami. Yogyakarta: Pustaka Baru Press.

17. Susilawati, L. K., Supriyadi, Nugrahaeni, P., \& Hizkia, D. (2017). Bahan Ajar: Teori dan Konsep Dasar Statika dan Lanjut (pp. 1-66). Universitas Udayana: Program Studi Psikologi Fakultas Kedokteran.

18. Tamin, O. Z. (1997). Perencanaan dan Pemodelan Transportasi Edisi Kedua. ITB.

19. Tamin, O. Z., Rahman, H., Kusumawati, A., Munandar, A. S., \& Setiadji, B. hario. (1999). Evaluasi Tarif Angkutan Umum dan Analisis Ability to Pay (ATP) dan Willingnes to Pay (WTP) di DKI Jakarta. Jurnal Transportasi, Forum Studi Transportasi Antar Perguruan Tinggi (FSTPT), Volume $1 \mathrm{~N}, 121-139$.

20. Umar, H. (2003). Metode Riset Perilaku Organisasi. Jakarta: Gramedia Pustaka Utama.

21. Walpole, R. E., \& Myers, R. H. (1995). Ilmu Peluang dan Statistika Untuk Insiyur dan Ilmuwan (Terjemahan) (Sembiring (ed.); Edisi Ke-4). Bandung: ITB PRESS.

22. Warpani, S. (2002). Pengelolaan Lalu Lintas dan Angkutan Jalan. Bandung: ITB PRESS. 
Wendy Natalia et.al. The effectiveness city of Balikpapan-Samarinda route selection with user characteristics analysis, and toll tariff analysis.

23. Widyaningsih, N. (2017). Evaluation Tol Gates Study in Karang Tengah of Toll road (Jakarta-Tangerang, West Java, Indonesia). International Journal of Civil and Structural Engineering Research, 5(1), 111-117. https://researchpublish.com/

24. Winaya, A., \& Caroline, J. (2019). Analisis Tarif Kereta Komuter Surabaya-Porong Ditinjau Dari Kemampuan Dan Kemauan Membayar (ATP Dan WTP) Pengguna Jasa. Institut Teknologi Adhi Tama Surabaya, ISSN 2685-6875. https://ejurnal.itats.ac.id/sntekpan/article/vie w/650/451

How to cite this article: Natalia W, Dwiatmoko $\mathrm{H}$, Widyaningsih $\mathrm{N}$. The effectiveness city of balikpapan-samarinda route selection with user characteristics analysis, and toll tariff analysis. International Journal of Research and Review. 2021; 8(8): 533-545. DOI: https://doi.org/10. 52403/ijrr.20210873 